\title{
CORRIGENDUM
}

\section{Perinatal mental health around the world: priorities for research and service development in Italy - CORRIGENDUM}

\section{Pietro Grussu, Ilaria Lega, Rosa Maria Quatraro and Serena Donati}

doi:10.1192/bji.2020.10

(C) The Authors 2020. This is an Open Access article, distributed Comm Commons Attribution licence (http://creativecommons.org/ licenses/by/4.0/), which permits unrestricted re-use, distribution, and reproduction in any medium, provided the original work is properly cited.

\section{CORRIGENDUM}

DOI: https://doi.org/10.1192/bji.2019.31, Published by Cambridge University Press, 27 November 2019

Keywords: Community mental health teams; depressive disorders; perinatal psychiatry; corrigendum

This article was published with an error on p. 9, which states that over the period from 2006 to 2012 , in ten Italian regions covering $77 \%$ of total national births, 567 cases of maternal suicide were recorded during pregnancy or within 1 year after birth, induced abortion or miscarriage. In fact there were only 67 cases of maternal suicide.

\section{Reference}

1. Grussu, P., Lega, I., Quatraro, R. M. and Donati, S. (2020) Perinatal mental health around the world: priorities for research and service development in Italy. BJPsych International, 17(1), 8-10.

\section{A snapshot of Iraqi psychiatry - CORRIGENDUM}

\section{Aws Sadik}

doi:10.1192/bji.2020.25

(c) The Author 2020. This is an Open Access article, distributed under the terms of the Creative Commons Attribution licence (http://creativecommons.org/ licenses/by/4.0/), which permits unrestricted re-use, distribution, and reproduction in any medium, provided the original work is properly cited.
DOI: https://doi.org/10.1192/bji.2020.19, Published online by Cambridge University Press, 24 April 2020

Keywords: Transcultural psychiatry; low and middle income countries; education and training

This article understates the number of psychiatrists and psychiatric hospitals in Iraq, appearing to exclude figures from the Kurdistan Region. In addition to the figures stated in the article, there are at least 40 qualified psychiatrists, three specialised mental health hospitals (for 40-60 patients) and two other psychiatric units inside general hospitals within Kurdistan. The number of consultant psychiatrists across Iraq appears to be over 160. I am grateful to Prof. Nazar M Mohammed Amin (University of Sulaimani) for providing this information.

\section{Reference}

1 Sadik A. A snapshot of Iraqi psychiatry. BJPsych Int 2020; 1-3. doi: 10.1192/bji.2020.19. 